\title{
Possibility of separating toxins from bacteria associated with sudden infant death syndrome using anion exchange chromatography
}

\author{
D B Drucker, H A Aluyi, J A Morris, D R Telford, B A Oppenheim, B A Crawley
}

\begin{abstract}
Aims: To develop techniques for the characterisation of toxins elaborated by a strain of Escherichia coli associated with sudden infant death syndrome (SIDS).

Methods: $E$ coli SIDS 04, isolated from the nasopharynx of a case of SIDS, was studied. Cell-free toxin preparations were standardised, their protein measured, and analytical separation of proteins achieved using sodium dodecyl sulphate-polyacrylamide gel electrophoresis (SDS-PAGE). Acetone precipitation of proteins was required prior to Coomassie blue staining of bands. Preparative separation was achieved on an anion exchange column using a programmed concentration gradient of $\mathrm{NaCl}$ in TRIS buffer. Fractions were tested individually or pooled for presence of lethal toxin including endotoxin. Lethal toxin was detected with the chick embryo test system. Endotoxin was measured using a chromogenic modification of the Limulus amoebocyte assay.
\end{abstract}

Results: Twenty one peaks were detected by chromatography. Ten individual, or pooled, fractions were assayed for endotoxin which ranged from $27-33 \mathrm{pg} / \mathrm{ml}$. Much greater variation was found when the same fractions were assayed in chick embryos. $E$ coli fractions varied considerably in lethal toxicity, from $0 / 10$ to 10/10 chick embryos killed/tested. Certain $E$ coli fractions tested individually (lethality four out of 10 to eight out of 10) proved more lethal (10 out of 10 ) if pooled prior to testing.

Conclusions: In $E$ coli infection associated with SIDS relatively low concentrations of extracellular protein are lethally toxigenic for the chick embryo model of SIDS. These proteins can be separated analytically by SDS-PAGE and preparatively by anion exchange chromatography. Toxicity of individual fractions is not correlated with endotoxin concentrations in samples tested.

The major cause of post perinatal infant death in the United Kingdom is cot death, or sudden infant death syndrome (SIDS). Several explanations have been proposed for its aetiology. These include developmental abnormality, ${ }^{12}$ hyperthermia, ${ }^{3}$ sleep apnoea, ${ }^{4}$ sleeping position, ${ }^{5}$ viral infection ${ }^{6}$ and bacterial infection. ${ }^{7}$ The common bacterial toxin hypothesis ${ }^{8}$ provides the only explanation of the characteristic age distribution of SIDS. Histological examination of lymphatic tissue from SIDS cases reveals changes typical of viral pneumonia in a higher proportion of SIDS babies than controls. ${ }^{9}$ In addition to viruses, toxigenic bacteria have been isolated from SIDS babies. ${ }^{1011}$ Viral infection may well enhance potency of bacterial toxins as influenza virus enhances activities of several bacterial toxins in infant ferrets. ${ }^{6}{ }^{12}$ Furthermore, synergy between different bacteria may have an important role in SIDS. In the gnotobiotic rat model combined Escherichia coli and Staphylococcus aureus infection leads to sudden death, but neither species does so in mono infection. ${ }^{13}$ Testing cell-free toxin preparations in the chick embryo revealed that there was a correlation between bacterial toxin and SIDS. ${ }^{14}$ More recently lethal synergy has been observed between toxin preparations from $E$ coli and $S$ aureus. $E$ coli endotoxin has previously been shown to enhance potency of $S$ aureus TSST-1 toxin in chick embryo. ${ }^{15}$ The actual molecular basis of the synergistic lethal toxicity of SIDS bacteria is unknown and cannot be readily established until biomolecular separation of toxins has been achieved.

As mediators of disease, toxins have necessarily attracted the attention of analytical biochemists who have recently studied a wide range of toxins. These have included leukocidin of $S$ aureus, ${ }^{16}$ separated by fast protein chromatography; vascular permeability factor of Bacillus cereus, ${ }^{17}$ separated chromatographically on DE-32 cellulose, sephadex G-100, and sephadex G-75; thetatoxin of Clostridium perfringens, ${ }^{18}$ separated by reverse phase chromatography; and enterotoxins $\mathrm{A}$ and $\mathrm{E}$ of $S$ aureus, ${ }^{19}$ separated by immunoaffinity chromatography. Clearly, a range of approaches has been used for toxin separation. However, none of these methods has been developed specifically for lethal toxins elaborated by bacteria associated with SIDS. Therefore, the aim of this study was to develop techniques for the analytical and preparative separation of toxins elaborated by a strain of $E$ coli associated with SIDS.

\section{Methods}

$E$ coli SIDS 04 was selected for study. It had originally been isolated from the nasopharynx of a 15 week old boy who had died of SIDS. The micro-organism was isolated together with $S$ aureus and two enterobacteria, Enterobacter aerogenes and Klebsiella pneumoniae. Isolation and speciation followed the methodology pre- 
viously described. ${ }^{714}$ The organism has also been the subject of synergy studies with $S$ aureus isolated from the same child. $E$ coli SIDS 04 was stored at $-80^{\circ} \mathrm{C}$ until required.

The dialysis membrane "overlay-on-agar" technique used in an earlier study ${ }^{14}$ was unsuitable for production of larger quantities of crude toxin preparation required for chromatography. Instead a dialysis membrane bag was used. The growth medium consisted of Hanks's balanced salt solution, HBSS (Sigma, Poole, Dorset) containing brain-heart infusion, BHI (Oxoid, Basingstoke) dialysate. The medium was prepared by overnight dialysis of $100 \mathrm{ml}$ autoclaved BHI against $100 \mathrm{ml}$ sterile, pyrogen-free HBSS. A membrane of 12 kilodalton exclusion limit was used. The medium in the dialysis bag was inoculated with one drop of an overnight culture of the test strain, then incubated at $37^{\circ} \mathrm{C}$ for 20 hours. Growth was assessed by measurement of absorbance at $550 \mathrm{~nm}$ using a double beam spectrophotometer (Pye-Unicam, Cambridge, England). Cells were removed by centrifugation at $3000 \times g$, then residual cells were removed using a filter of $0 \cdot 20 \mu \mathrm{M}$ pore size (Gelman Sciences). The absorbance value was used to standardise the cell-free crude toxin preparation which was desalted by dialysis against three changes of distilled water. After cooling to $<4^{\circ} \mathrm{C}$ proteins were precipitated using two volumes of acetone (at $-20^{\circ} \mathrm{C}$ ). After mixing with a rotamixer the preparation was allowed to stand for 15 minutes. Protein precipitate was recovered by centrifugation at $3000 \times g$ for 15 minutes. The precipitate was washed twice with acetone-water $(1: 1, \mathrm{v} / \mathrm{v})$ and stored at $4^{\circ} \mathrm{C}$ before use. This permitted concentration of proteins which resulted in a larger number of bands being visualised following SDS-PAGE separation.

\section{TOXIN ANALYSIS}

Crude toxin was (a) separated analytically, using SDS-PAGE, (b) separated preparatively, using anion exhange chromatography, (c) assayed for lethal toxicity, using the chick egg test system ${ }^{14}$ and (d) assayed for the presence of endotoxin ${ }^{14}$ using a chromogenic modification of the Limulus amoebocyte assay (Quadratech Ltd, Epsom). Toxicity was determined for separated components as well as for the complete mixture of substances present in crude toxin. This was to pinpoint those fractions containing lethal toxin.

SDS-PAGE required concentrated toxin preparations so that it was necessary to freezedry toxin preparation, then to redissolve in $0 \cdot 125 \mathrm{M}$ TRIS buffer, $\mathrm{pH}$ 6.8. A modified discontinuous system was used. Samples were dissolved in the TRIS buffer which also contained $4 \% \mathrm{w} / \mathrm{v}$ sodium dodecyl sulphate, $20 \%$ $\mathrm{v} / \mathrm{v}$ glycerol, $10 \% \mathrm{v} / \mathrm{v}$ mercaptoethanol and $0.025 \% \mathrm{w} / \mathrm{v}$ bromophenol blue (the tracking dye), at $90^{\circ} \mathrm{C}$ for four minutes. Electrophoresis was performed in a vertical slab unit (Hoffer Scientific Instruments, Newcastle) and run at a constant $30 \mathrm{amp} / 240 \mathrm{~V}$ through $5 \%$ polyacylamide stacking gel and $12 \%$ resolving gel, both $1 \mathrm{~mm}$ thick, for five hours. Protein bands were visualised by staining with $0.025 \%$ Coomassie blue R-250. Molecular weights were calculated by comparison with standard markers- $14 \cdot 2,20.1,24,29,36,45$ and 66 kilodaltons. Gels were dehydrated with ethanol. All electrophoresis reagents were purchased from Biorad Laboratories (Herts).

As a preparative separative technique, chromatography ${ }^{10}$ was preferred. Preliminary studies using high performance liquid chromatography (HPLC) ${ }^{20}$ provided unsatisfactory separations of toxins, irrespective of whether gel protein chromatography (GPC), reversed phased, or ion exchange columns were used. The largest number of peaks obtained was only four. Unexpectedly, far better results were obtained from the samples of interest in this study, using a programmed gradient low pressure analysis on an anion exchange column after other types of column had failed to separate the proteins of interest. Freeze-dried samples were redissolved in

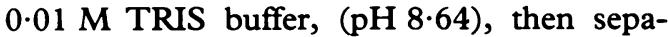
rated using an Econo-Pac $Q$ cartridge in Econo System (Biorad Laboratories, Herts) with an ultraviolet detection at $280 \mathrm{~nm}$. The column was equilibrated with $0.01 \mathrm{M}$ TRIS buffer (buffer A) and a flow rate of $8.5 \mathrm{ml} /$ minutes was used for protein separation. The following programme was used: $100 \%$ buffer A, two minutes; a linear gradient $0-40 \%$ of $1.0 \mathrm{M} \mathrm{NaCl}$ in $0.01 \mathrm{M}$ TRIS (buffer B), 18 minutes; a further linear gradient of $40-100 \%$ buffer $B$, seven minutes; re-equilibration with $100 \%$ buffer $\mathrm{A}$, two minutes.

\section{Results}

SDS-PAGE proved an excellent analytical technique for separation of extracellular proteins of $E$ coli SIDS 04 but, obviously, not endotoxin. Unconcentrated samples derived from $E$ coli produced very few visible bands; acetone precipitated protein samples yielded about 28 bands. The proteins resolved had molecular weights in the range 12-70 kilodaltons. This number of bands represented the minimum number of peaks to be resolved in a corresponding "ideal" chromatogram. Anion exchange chromatography on a strong anion exchanger, Econo-Pac Q, detected at least 21 components in the crude toxin preparation (figure) which compares well with the "ideal chromatography" number of peaks. The Econ-

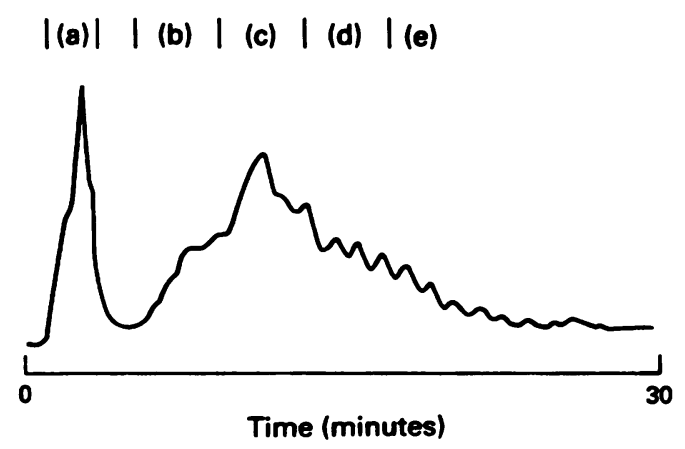

Fractionation of $E$ coli extracellular crude toxin by anion exchange on Econo-Pac $Q$. 
osystem was able to collect fractions which could be assayed for toxin individually or as pooled functions. Pooled functions were tested first and revealed that only one pooled fraction totally lacked lethal toxicity for the chick embryo (table). Pooled fraction "a" killed $10 / 10$ embryos tested. The individual components $a_{1}, a_{2}, a_{3}, a_{4}, a_{5}$ of pooled fraction " $a$ " were subsequently tested individually; their lethal toxicity is also recorded in the table. All five individual fractions displayed lethal toxicity but less than the pooled fractions (a). Endotoxin was present at similar concentrations in all samples in the range $27-33 \mathrm{pg} / \mathrm{ml}$.

\section{Discussion}

The finding that acetone precipitation was required to permit SDS-PAGE detection of $E$ coli extracellular proteins indicates the relatively low concentrations of such proteins released by $E$ coli. However, the fact that so many chromatography fractions proved lethally toxigenic indicates the highly toxigenic nature of several such extracellular proteins. The chromatographic separation of bacterial toxins by HPLC has been reviewed elsewhere. ${ }^{20}$ HPLC is still not widely used for bacterial toxin analysis, even though it is now a preferred method for separating toxins from snake venoms, such as from Leakey's sawscaled viper, ${ }^{21}$ cobras, $^{22}$ and tiger rattle snakes. $^{23}$

Bacterial toxins have recently been separated using HPLC based on size exclusion ${ }^{24}$ and FPLC on hydroxyapatite, ${ }^{25}$ but even the latter separations also involved ammonium sulphate precipitation followed by separations on DEAE cellulose and Sephadex G-75. The difficulties encountered in preliminary attempts to separate SIDS associated lethal toxins by HPLC may indicate that HPLC is not well suited to such separation in practice, despite the technique's theoretical promise. Obviously, HPLC offers exceptional resolving power so that a limited number of column packing types are used by most chromatographers. In other words the HPLC column types to hand in this study would not be expected to be ideal in all cases. The advantage, in this study, of the Econosystem was the ability to test a range of inexpensive columns in cartridge form during method development. This permitted selection of a column well suited to the analyte. The result was a five-fold increase in numbers of peaks detected, compared with

Lethal toxicity for chick embryo and endotoxin content of $E$ coli supernatant fractions separated by anion exchange chromatography

\begin{tabular}{lcll}
\hline Sample & $\begin{array}{l}\text { Fractions } \\
\text { pooled }\end{array}$ & $\begin{array}{l}\text { Lethality for chick embryo } \\
\text { (killed/tested) }\end{array}$ & $\begin{array}{l}\text { Endotoxin } \\
\mathrm{pg} / \mathrm{ml}\end{array}$ \\
\hline $\mathrm{a}$ & $1-5$ & $10 / 10$ & 30 \\
$\mathrm{~b}$ & $6-14$ & $2 / 10$ & 31 \\
$\mathrm{c}$ & $15-20$ & $3 / 9$ & 33 \\
$\mathrm{~d}$ & $21-24$ & $0 / 10$ & 33 \\
$\mathrm{e}$ & $25+$ & $2 / 10$ & 32 \\
$\mathrm{a}_{1}$ & 1 & $4 / 10$ & 27 \\
$\mathrm{a}_{2}$ & 2 & $8 / 10$ & 28 \\
$\mathrm{a}_{3}$ & 3 & $8 / 10$ & 31 \\
$\mathrm{a}_{4}$ & 4 & $8 / 10$ & 33 \\
$\mathrm{a}_{5}$ & 5 & $7 / 10$ & 31 \\
\hline
\end{tabular}

the HPLC methods tested. The concentrations of endotoxin present in all samples were above our detection limit of $10 \mathrm{pg} / \mathrm{ml}^{26}$ but did not correlated with toxicity of individual fractions. In other studies limits of detection of toxins have been decreased by the deliberate inclusion of sublethal amounts of a second toxin in the assay system. Previous studies ${ }^{152729}$ have shown that the lethality of $E$ coli toxin can be enhanced with $S$ aureus TSST-1 toxin. What is now apparent is that with toxigenic bacteria associated with SIDS, other interactions between toxins may have an important role in its pathogenesis. Recently, lethal synergy between $E$ coli and $S$ aureus toxin preparations acting in combination has been observed. From our study it appears that within a single SIDS bacterial strain there must be several lethal toxins, and that these may possibly act in combination is evidenced by data for pooled fraction " $a$ " and its constituent fractions (table).

The common bacterial toxin hypothesis, ${ }^{8}$ as originally proposed, suggested that SIDS might occur if an infant lacking appropriate immunity encountered a commonly occurring bacterial strain that produced a lethal toxin. Clearly, there must be a large number of strains $^{714}$ and lethal toxins. Nevertheless, if it is found that a few, specific, toxins have a powerful role in enhancing other toxins then it might be possible to target such toxins in the prophylaxis of SIDS.

We gratefully acknowledge the invaluable advice on protein separation provided by $\mathrm{Dr} C \mathrm{~A}$ Shuttleworth (Department of Biochemistry and Molecular Biology), Professor K T Dougla (Department of Pharmacy) at the University of Manchester and by various scientists of Biorad Laboratories (Heme Hempstead).

1 Werthammer J, Brown E, Weff RK, Taesch HW, Sudden infant death syndrome in infants with bronchopulmonary infant death syndrome in infants with
dysplasia. Pediatrics $1982 ; 69: 301-4$.

2 Gordon D, Cohen RJ, Kelly D, Akselrod S, Shanron DC Sudden infant death syndrome: abnormalities in short term fluctuations in heart rate and respiratory activity. Pediatrics Res 1985;18:921-6.

3 Bacon CJ. Overheating in infancy. Arch Dis Child 1983, 58:673-4.

4 Steinschneider A, Weinstein SL, Diamond E. The sudden infant death syndrome and apnoea/obstruction durin neonatal sleep and feeding. Pediatrics 1982;70:858-63.

5 Fleming PJ, Gilbert R, Azaz Y, et al. Interaction between bedding and sleep position in the sudden infant death syndrome: a population based control study. $\mathrm{Br} \mathrm{Med} f$ 1990;301:85-9.

6 Jakeman KJ, Rushton DI, Smith H, Sweet C. Exacerbation of bacterial toxicity to infant ferrets by influenza virus: possible role in sudden infant death syndrome. $₹$ Infect $D$ is $1991 ; 163: 35-40$.

7 Telford DR, Morris JA, Hughes P, et al. The nasopharyngea bacterial flora in the sudden infant death syndrome. $f$ Infect 1989;18:125-30.

8 Morris JA, Haran D, Smith A. Hypothesis: common bacterial toxins are possible cause of sudden infant death syndrome. Med Hypoth 1987;22:211-22.

9 Entrup M, Brinkman B. Histologische Lungenbefund beim plotzlichen Kindstod. $Z$ Rechtsmed 1990;103:425-33.

10 Watt B. Infant botulism - one cause of cot death. Microbio Sci $1987 ; 4: 57-8$.

11 Bettleheim K, Goldwater PN, Dwyer BW, Bourne AJ, Smith DL. Toxigenic Escherichia coli associated with sudden infant death syndrome. Scand $\mathcal{F}$ Infant Dis 1990;22:467-76.

12 Jakeman KJ, Smith $\mathrm{H}$, Sweet $\mathrm{C}$. Influenza virus enhancement of membrane leakiness induced by staphylococcal ment of membrane leakiness induced by staphylococcal a-toxin, diphthe

13 Lee S, Barson AJ, Drucker DB, Morris JA, Telford DR. Lethal challenge of gnotobiotic weanling rats with bacterial isolates from cases of sudden infant death syndrome (SIDS). $\mathcal{f}$ Clin Pathol 1987;40:1393-6.

4 McKendrick N, Drucker DB, Morris JA, Telford DR Barson AJ, Oppenheim BA, Crawley BA. Bacterial toxins: a possible cause of cot death. F Clin Pathol 1992 45:49-53.

15 De Azevedo JCS, Lucken RN, Arbuthnott JP. Chick embryo 
assay for staphylococcal toxic shock syndrome toxin-1. Methods Enzymol 1988:165:344-7.

16 Finck-Barbancon V, Prevost G, Piemont Y. Improved purification of leukocidin from Staphylococcus aureus and toxin distribution among hospital strains. Res Microbiol 1991;142:75-85.

17 Shinagawa K, Ueno S, Konuma H, Matsusaka N, Sugii S Purification and characterisation of the vascular permeability factor produced by Bacillus cereus. F Vet Med $S_{c i}$ 1991;53:281-6.

18 Tweten RK, Harris RW, Sims PJ. Isolation of a tryptic fragment from Clostridium perfringens theta toxin that contains sites for membrane binding and self aggregation. f Biol Chem 1991;266:12449-54.

19 Shinagawa $K$, Mitsumori $M$, Matsusaka N, Sugii $S$. Purification of staphylococcal enterotoxins $A$ and $E$ by immunoaffinity chrococcal enterotoxins $A$ and $E$ by immunoaffinity chromatography using a murine monoclonal antibody with dual specificity

20 Drucker DB. Microbiological applications of high performance liquid chromatography, Cambridge: Cambridge University Press, 1987.

21 Desmond HP, Crampton JM, Theakston RD. Rapid isolation and partial characterization of two phospholipases from Kenyan Echis carinatus leakeyn (Leakey's saw-scaled viper) venom. Toxicon 1991;29:536-9.

22 Shafqat J, Siddiai AR, Zaidi $\mathrm{ZH}$, Jornvall $\mathrm{H}$. Extensive multiplicity of the miscellaneous type of neurotoxins from the venom of the cobra Naja naja and structural characterization of major components. FEBS Lett 1991;284:70-2

23 Weinstein SA, Smith LA. Preliminary fractionation of tiger rattlesnake (Crotalus tigris) venom. Toxicon 1990 28:1447-55.

24 Czuprynski CJ, Noel EJ, Ortiz-Carranza O, Srikumaran S. Activation of bovine neutrophils by partially purified Pasteurella haemolytica leukotoxin. Infect Immun 1991; 59:3126-33.

25 Honda T, Shiba A, Seo S, Yamamoto J, Matsuatama J, Miwatani T. Identity of hemolysins produced by Bacillus thuringiensis and Bacillus cereus. FEMS Microbiol Lett 1991;63:205-9.

26 Rao PN, Dube DA, Weightmann NC, Oppenheim BA Morris J. Prediction of septicaemia following endouroogical manipulation of stones in the upper urinary tract.

27 Schlievert PM Enhancement of host susceptibility to lethal endotoxin shock by staphylococcal pyrogenic exotoxin type C. Infect Immun 1982;36:123-8.

28 Keane WF, Gekker G, Schievert PM, Peterson PK Enhancement of endotoxin-induced renal tubular cell injury by toxic shock syndrome toxin-1. Am 7 Pathol 1986;122:169-76.

29 Bohash GA, Schlievert PM. Detection of endotoxin by enhancement with toxin shock syndrome toxin-1 (TSST1). Methods Enzymol 1988;165:302-6. 